\title{
Orally disintegrating tablet: formulation design and optimisation using Response Surface Methodology
}

\author{
Biljana Nestorovska-Gjosevska*, Marija Glavas-Dodov, Katerina Goracinova \\ Department of Pharmaceutical Technology, Faculty of Pharmacy, \\ University „Ss Cyril and Methodius“ Vodnjanska 17, 1000, Skopje, Macedonia
}

Received September 2005, accepted December 2005

\begin{abstract}
The objective of this study was to develop diazepam orally disintegrating tablets and to optimize tablets characteristics using response surface methodology (RSM). Tablets were prepared by direct compression of mixture containing mannitol, copovidone, crosspovidone flavor and lubricant. A full factorial design for 2 factors at 3 levels each was applied to investigate the influence of 2 formulation variables on the mechanical strength/hardness, the percent of friability, disintegration time and dissolution of the poorly soluble active ingredient. The amounts of copovidone and crosspovidone were taken as independent variables. All data were analyzed by using statistical program.

The results of multiple linear regression analysis revealed that for obtaining a rapidly disintegrating dosage form, tablets should be prepared using an optimum concentration of crospovidone and copovidone. A contour plot is also presented to graphically represent the effect of the independent variables on the tablet hardness, disintegration time, percentage friability and dissolution. A checkpoint batch was also prepared to prove the validity of the evolved mathematical model.

3 level factorial design allowed us to obtain ODT with rapid disintegration and dissolution of the active ingredient with desirable properties of low tablet friability and appropriate mechanical strength (hardness) of the tablet.
\end{abstract}

Key words: orally disintegrating tablets, experimental design, response surface methodology.

\section{Introduction}

Recent developments in technology have presented viable dosage alternatives for patients who may have difficulty swallowing tablets. Traditional tablets and capsules may be inconvenient or impractical for some patients. Geriatric and pediatric patients experience difficulty in swallowing conventional tablets which leads to poor patience compliance. This problem is overcomed with use of drug delivery system known as orally disintegrating tablets. These are novel types of tablets which disintegrate/dissolve/disperse in saliva for 60 seconds or less $(1,2,3)$.

They are also suitable for the mentally ill, the bedridden and patients who do not have easy access to water. The be-

\footnotetext{
* Билјана Несторовска-Ѓошевска

e-mail adress: biljanag@yahoo.com

* Biljana Gjosevska is employed in Jaka 80, Radovis,

and part of the experimental work was undertaken in their Laboratories.
}

nefits in terms of patience compliance, rapid onset of action, possibility for increased bioavailability, and good stability make these tablets popular as a dosage form of choice in the current market (2). Orally disintegrating tablets are suitable formulation for all active substances which can be orally administered (3).

A pharmaceutical formulation is composed of several composition factors and process variables. These factors and variables not only affect the characteristic property of the dosage form but also make it difficult to formulate. Formulation experience with pharmaceutical preparation generally can guide a formulation expert to select those variables that most likely have an effect on those corresponding responses (4).

Traditional formulation designs were based on trial and error. It is time-consuming, unreliable, costly and often unsuccessful. The rapid development of statistical experimental designs, optimisation techniques and computer technologies provide an effective method for modelling 
complicated multivariate drug formulations. Pharmaceutical formulation thus has been brought into a new era (5).

When a target is to evaluate one or more tablet properties, the experimenter can make use of a set of tools and techniques known under experimental research methodology. In general, adopting such an experimental approach means defining the problem which one is going to cope with by determining the objectives, the possible constraints in the component proportion and the response variables under study (6).

Many statistical experimental designs have been recognized as useful techniques to optimize the process variables. Different types of designs as screening, mixture, response surface, have been used for preformulation evaluations $(7,8)$.

Response surface Methodology (RSM) is a widely practiced approach in the development and optimization of drug delivery devices. Based on the principal of design of experiments (DoE), the methodology encompasses the use of various types of experimental designs, generation of polynomial equations, and mapping of the response over the experimental domain to determine the optimum formulation. The technique requires minimum experimentation and time, thus providing to be far more effective and cost effective than the conventional methods of formulating dosage forms. It is a collection of statistical and mathematical techniques, useful for developing, improving and optimizing processes $(9,10)$. It also has an important application in the design, development and formulation of new products as well as in the improvement of existing product designs. The basic components of response surface methodology include experimental design, regression analysis and optimisation algorithms which are used to investigate the empirical relationship between one or more measured responses and a number of independent variables, with the ultimate goal of obtaining an optimal problem solution. Also, interaction between different factors, which can influence the target responses, may be detected $(11,12,13)$.
The current study aims at developing and optimizing an orally disintegrating tablet of diazepam using RSM.

\section{Experimental}

\section{Materials}

Diazepam was supplied from Fabbrica Italiana Sintetici Italy, Mannitol direct compressible grade from Merck KgAGermany, Copovidone and Crosspovidone from BASF KgA, Germany and magnesium stearate from Mosselman, Belgium.

\section{Methods}

\section{Experimental design}

Response surface experimental design was used to optimize and evaluate main effects, interaction effects, and quadratic effects of the formulation ingredients on the percent of friability, hardness, disintegration time and drug release. $\mathrm{A} 3^{2}$ randomized full factorial design is suitable for exploring response surfaces and constructing polynomial models (10).

In this design 2 factors were evaluated, each at 3 levels, and experimental trials were performed at all 9 possible combinations. The amount of the binding agent, copovidone (X1) and the amount of superdisintegrant, crosspovidone (X2) were selected as independent variables. The percent of friability, hardness, disintegration time and drug release were selected as dependent variables.

The composition of formulations of the factorial design is shown in Table 1.

Preparation of Diazepam orally disintegrating tablets

The raw materials were passed through a No.1.2 screen prior mixing. Diazepam, copovidone and crosspovidone were homogeneously blended with directly compressible mannitol as a diluent. The mixture than was blended with the fixed quantity of the lubricant magnesium stearate and compressed into flat faced tablets (6 mm diameter) using rotate tablet compression machine.

Table 1. Responce surface experimental design

\begin{tabular}{|c|c|c|c|c|c|c|}
\hline Series & $\begin{array}{c}\text { Diazepam } \\
(\%, w / w)\end{array}$ & $\begin{array}{c}\text { Flavor } \\
(\%, w / w)\end{array}$ & $\begin{array}{c}\text { Magnesium } \\
\text { stearate } \\
(\%, w / w)\end{array}$ & $\begin{array}{c}\text { Copovidone } \\
(\%, w / w)\end{array}$ & $\begin{array}{c}\text { Crosspovidone } \\
(\%, w / w)\end{array}$ & $\begin{array}{c}\text { Mannitol } \\
\text { DC } \\
(\%, w / w)\end{array}$ \\
\hline 1 & 2.6 & 0.2 & 3.0 & 0.50 & 1.0 & 92.70 \\
\hline 2 & 2.6 & 0.2 & 3.0 & 5.00 & 1.0 & 88.20 \\
\hline 3 & 2.6 & 0.2 & 3.0 & 0.50 & 5.0 & 88.70 \\
\hline 4 & 2.6 & 0.2 & 3.0 & 2.75 & 1.0 & 90.45 \\
\hline 5 & 2.6 & 0.2 & 3.0 & 0.50 & 3.0 & 90.70 \\
\hline 6 & 2.6 & 0.2 & 3.0 & 2.75 & 3.0 & 88.45 \\
\hline 7 & 2.6 & 0.2 & 3.0 & 5.00 & 5.0 & 84.20 \\
\hline 8 & 2.6 & 0.2 & 3.0 & 5.00 & 3.0 & 86.20 \\
\hline 9 & 2.6 & 0.2 & 3.0 & 2.75 & 5.0 & 86.45 \\
\hline
\end{tabular}




\section{Evaluation of tablet properties}

Hardness /Mechanical strength

The tablet hardness was measured by hardness tester (VanKelVK200 ,USA)

\section{Percent Friability}

The friability of tablets was determined using friability tester (VanKel, USP). The method of determination was according to USP28 method. The percent friability was obtained from 20-tablet sample.

\section{Disintegration Time}

The disintegration time was measured by using according USP 28 method for disintegration of tablets (VanKel 6Basket System,USP)with purified water at $37{ }^{\circ} \mathrm{C}$ as disintegration medium. The mean and standard deviation were calculated from six determinations.

\section{Percent Drug Release}

Dissolution studies were performed employing USP 28 paddle method (VanKel Dissolution tester, VK-700, USA), $900 \mathrm{ml}$ of $0.1 \mathrm{~mol} / \mathrm{l} \mathrm{HCl}$ as dissolution medium at $50 \mathrm{rpm}$. The samples were analyzed using HPLC method (USP28).

\section{Tablet assay}

The tablets were assayed for drug content according USP 28 monograph for Diazepam tablets (Varian, HPLC system UV/vis variable wavelength detector, USA).

\section{Statistical analysis}

The data obtained from the evaluation of the tablet characteristics were analyzed using Statgraphics ${ }^{\circledR}$ plus, Windows software program (Version 5.1, USA).

\section{Results and discussion}

\section{Tablet evaluation}

All nine formulations of the experimental response surface design were prepared as different combinations of independent variables, copovidone (0.5-5\%) and crosspovidone (1-5\%) and the following parameters were analyzed: hardness, tensile strength, friability, disintegration and dissolution of the tablets.

The results of analysis of dependent variables- responses for each formulation are presented in Table 2.

The expressed results are mean values, for the hardness and friability determination of 20 tablets, disintegration of 12 and dissolution of 6 tablets.

During the preparation of the tablets, lower mechanical strength and increased friability for the series 1, 3, 5 under the applied pressure during tabletting were gained (RS design, quantity of the binding agent copovidone $0.5 \%$ ). Adequately, the friability of these formulations was not within the required limit, as described in USP28.

The hardness and friability were improved with increase of the concentration of the dry binder in the formulations. Complete release of diazepam from the prepared formulations was noticed after 20 and/or 30 min, showing differences in drug release rates due to different composition among series within the first 10 and $20 \mathrm{~min}$. Disintegration of the tablets showing appropriate mechanical strength was fastest for series 9 (combination with $2.75 \%$ of copovidone and $5 \%$ of crosspovidone). However, the results given in Table 2 express that percent of drug release and the time of disintegration are not parameters that could be easily evaluated (followed) and are complex functions which mathematical expression and dependence (effect) of independent variable will be obtained from the experimental design.

Table 2. Results of the determination of the dependent variables for each series

$\begin{array}{ccccc}\text { Series } & \begin{array}{c}\mathrm{Y}_{1}{ }^{\mathrm{a}} \\ (\mathrm{kp})\end{array} & \begin{array}{c}\mathrm{Y}_{2}{ }^{\mathrm{b}} \\ (\mathrm{MPa})\end{array} & \begin{array}{c}\mathrm{Y}_{3}{ }^{\mathrm{c}} \\ (\%)\end{array} & \begin{array}{c}\mathrm{Y}_{4}{ }^{\mathrm{d}} \\ (\mathrm{sec})\end{array} \\ 1 & 1 & 0.30 & 1.050 & 20 \\ 2 & 5.5 & 1.80 & 0.062 & 100 \\ 3 & 1 & 0.31 & 1.163 & 10 \\ 4 & 4 & 1.27 & 0.078 & 55 \\ 5 & 1 & 0.31 & 1.091 & 12 \\ 6 & 4 & 1.28 & 0.085 & 19 \\ 7 & 5.5 & 1.80 & 0.051 & 40 \\ 8 & 5.5 & 1.81 & 0.055 & 60 \\ 9 & 4 & 1.27 & 0.085 & 12 \\ \text { a Y1 - Hardness } & \text { b Y2 - Tensile strength } & \text { c Y3 - Friability } & \text { d Y4 - Disintegratione }\end{array}$

a Y1 - Hardness b Y2 - Tensile strength c Y3 - Friability d Y4 - Disintegratione

$$
\mathrm{Y}_{5}(\%)^{\mathrm{e}}
$$

$10 \mathrm{~min} \quad 30 \mathrm{~min}$

$\begin{array}{lll}95.80 & 97.02 & \text { complete diss. } \\ 95.08 & 98.30 & \text { complete diss. } \\ 95.53 & 95.08 & \text { complete diss. } \\ 96.20 & 97.20 & \text { complete diss. } \\ 94.68 & 97.30 & \text { complete diss. } \\ 94.30 & 95.60 & \text { complete diss. } \\ 93.16 & 95.06 & \text { complete diss. } \\ 93.89 & 97.41 & \text { complete diss. } \\ 93.11 & 96.15 & \text { complete diss. }\end{array}$

Y5 - Dissolution of diazepam in $0.1 \mathrm{~mol} / \mathrm{l} \mathrm{HCl}$ 


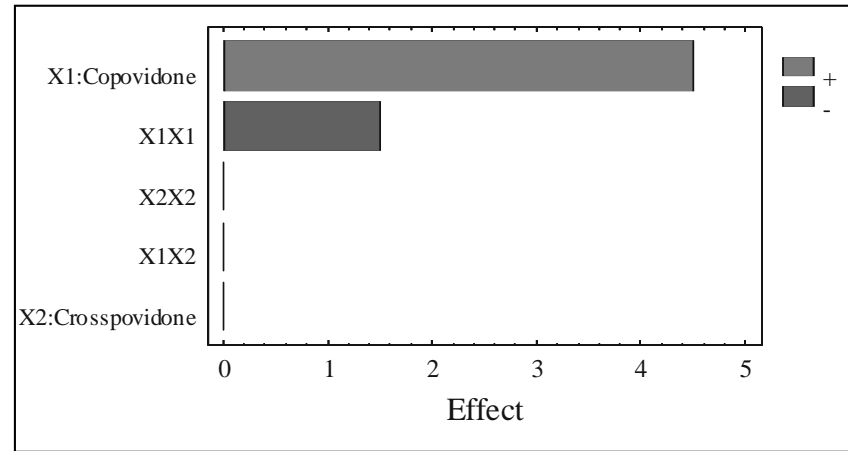

Fig. 1. Standard pareto chart showing the effects of independent variables X1 (copovidone) i X2 (crosspovidone) and their combined effects on the response Y1 (hardness of the tablets)

\section{Factorial design}

\section{Hardness of tablets}

The relationship between the hardness of the tablets and the independent variables is presented in Fig. 1.

The standardized pareto chart at Fig. 1. depicts the main effect of the independent variable on the tablet hardness. The length of each bar in the graph indicates the effect of these factors and the level of their responses. From Figure 1 it can be interfered that the factor $\mathrm{X} 1$ has a main effect on the response Y1. Factors X2, X1X2, X2X2 did not show significant effects on the $\mathrm{Y} 1$ response (the hardness of the tablets). With excluding of the factors which do not have significant effect on the response, the mathematical relationship in the form of polynomial equation for the measured response Y1 would be:

\section{$\mathrm{Y} 1=0.75+1 * \mathrm{X} 1 \quad$ (Eq. 1$)$}

Results presented in Fig. 1 and Eq. 1 show that the most significant effect on the hardness of the tablets has the binding agent copovidone, without the significant influence of the interaction between the factors i.e. between the binding and disintegrating agent.

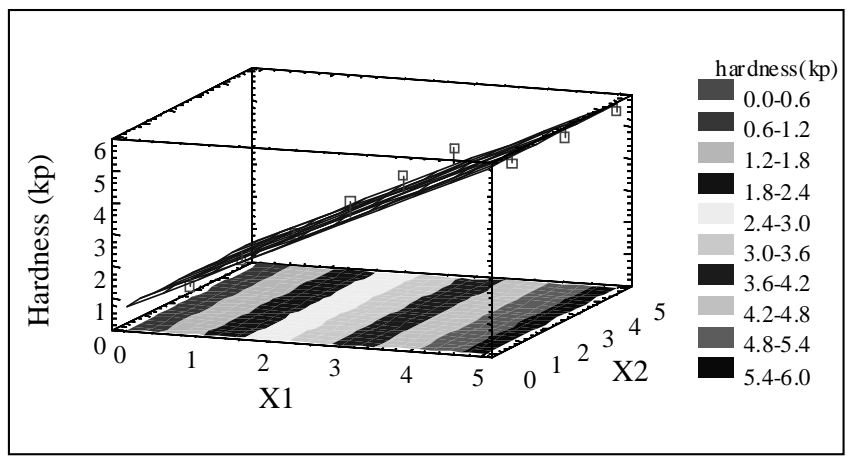

Fig. 2. Response surface plots showing the effect of independent variable X1 (copovidone) on response Y1 (hardness of the tablets)
Also, Fig. 2 illustrates that the quantity of the binding agent is a factor which shows significant and linear effect on the hardness of the tablets (when applied constant punch pressure).

\section{Friability of the tablets}

The mathematical relationship in the form of polynomial equation for the measured response, Y3 is listed below:

\section{$\mathrm{Y} 3=1.37834-0.750494 * \mathrm{X} 1+0.0280278 * \mathrm{X} 2+0.0979753 *$ $\mathrm{X} 1 \wedge 2-0.00688889 * \mathrm{X} 1 \mathrm{X} 2$ (Eq.2)}

The polynomial equation represents the quantitative effect of process variables (X1 and X2) and their interaction on the response Y3. The values of coefficients X1 and $\mathrm{X} 2$ are related to the effect of these variables on the response Y3. A positive value represents an effect that favor the optimisation, while a negative value indicates an antagonistic effect.

The main effect on the independent variables on the dependent variables was further investigated using a pareto chart (Fig. 3) and interaction plot (Fig. 4). Also, the relationship between the dependent and independent variables

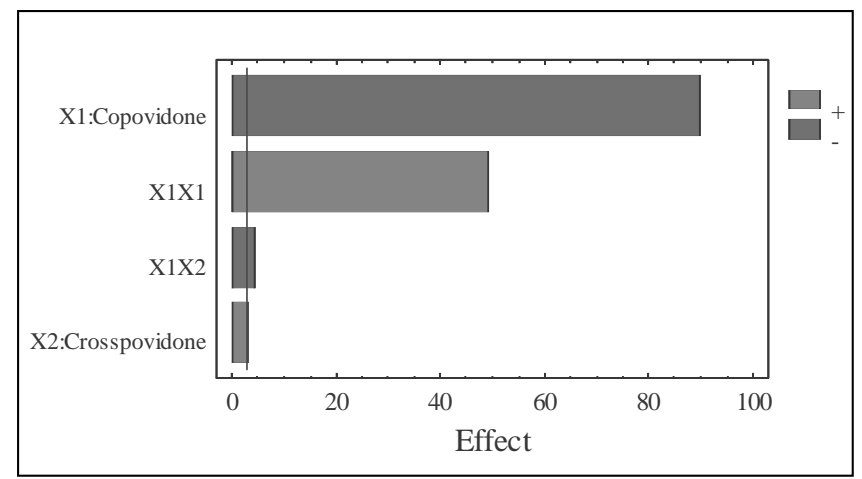

Fig. 3. Standard pareto chart showing the effects of independent variables X1 (copovidone) and $\mathrm{X} 2$ (crosspovidone) and their combined effects on the response Y3 (friability of the tablet)

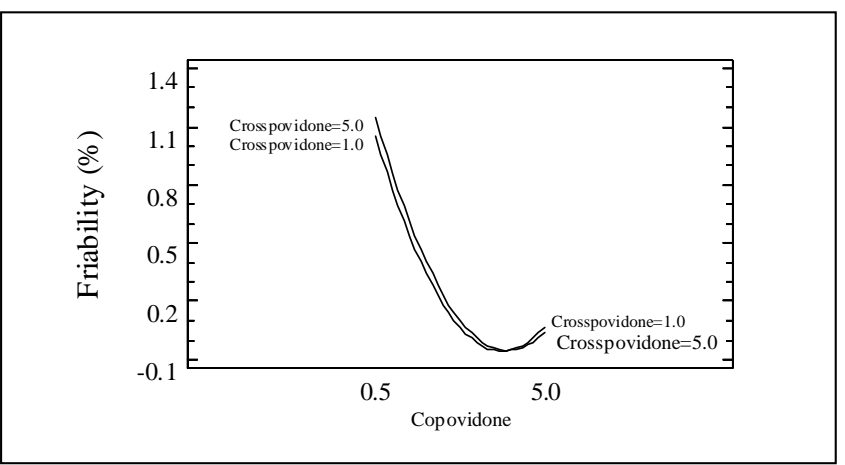

Fig. 4. Interaction plot showing the effects of interactions between the factors on the friability of the tablets

Maced. pharm. bull., 51 (1,2) 15-22 (2005) 


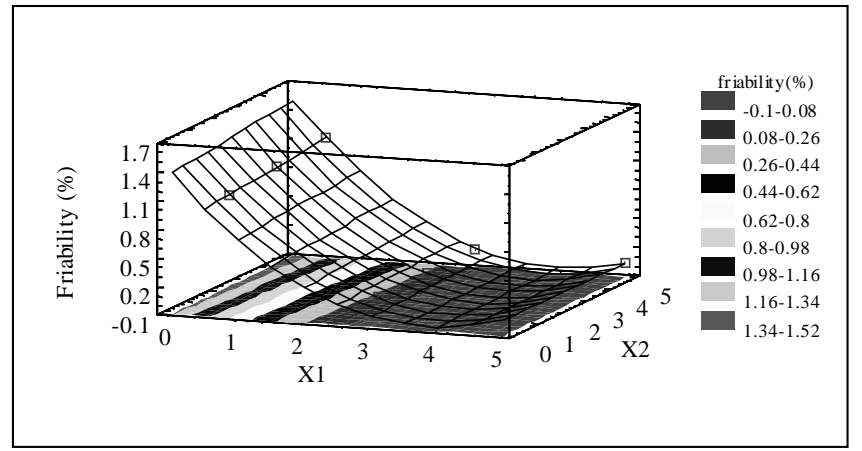

Fig. 5. Response surface plots showing the effect of independent variables, varying ratio of (X1) copovidone and (X2) crosspovidone on response Y3 (friability of the tablet)

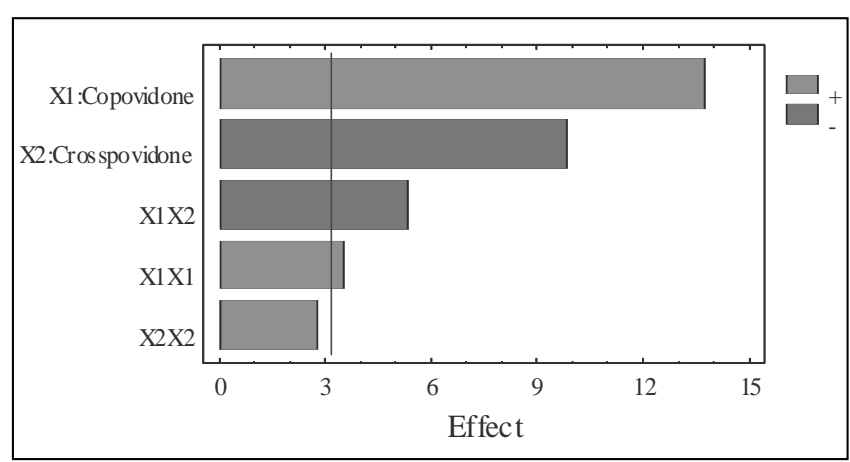

Fig. 6. Standard pareto chart showing the effects of independent variables X1 (copovidone) and $\mathrm{X} 2$ (crosspovidone) and their combined effects on the response Y4 (disintegration of the tablet)

was further elucidated using response surface plots (Fig. 5). Fig. 3 depicts the main effect of the independent variable on the friability of the formulations.

From Figs. 3 and 4 it can be interfered that the factors: $\mathrm{X} 1, \mathrm{X} 1 \mathrm{X} 1$ (quadratic effect of copovidone), X1X2 (interaction effect of copovodone and crosspovidone) and X2 have a significant effect on the response Y3.

Fig. 5 further explains the effect of X1 and X2 ratios on the friability of the tablets. From response surface plots it is clear that the ratio of copovidone and crosspovidone has a major effect on determining friability of formulations. Figure 5 shows that at lower concentrations of copovidone the friability increases.

\section{Disintegration of tablets}

Fig. 6 represents the influence of independent variables on disintegration.

Mathematical relationship in a form of polynomial equation is listed below:

$\mathrm{Y} 4=19.2428+7.36214 * \mathrm{X} 1-1.77778 * \mathrm{X} 2+2.30453 *$ $\mathrm{X} 1 \wedge 2-2.77778 * \mathrm{X} 1 * \mathrm{X} 2$ (Eq.3)

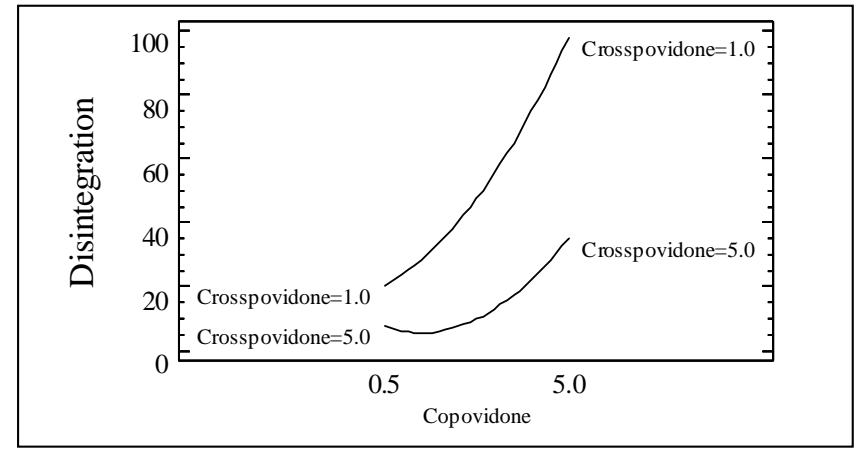

Fig. 7. Interaction plot showing the effects of interactions between the factors on the disintegration of the tablets

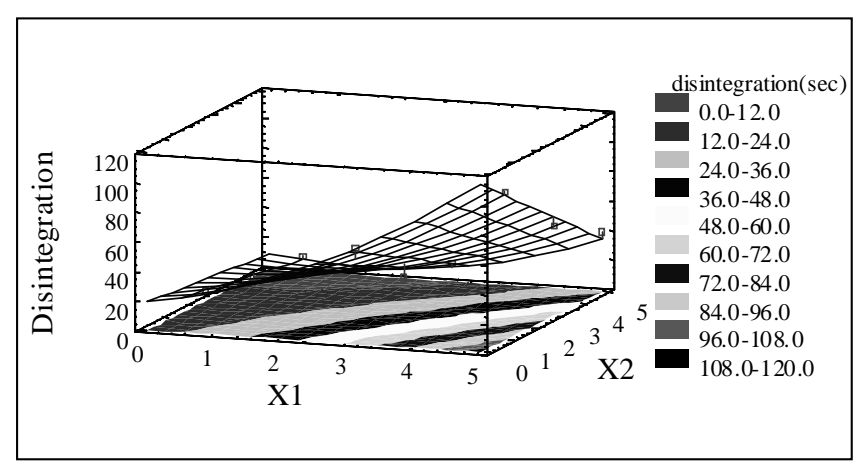

Fig. 8. Response surface plots showing the effect of independent variables, varying ratio of (X1) copovidone and (X2) crosspovidone on response Y4 (disintegration of the tablet

The main effect on the disintegration time depend on copovidone and crosspovidone quantity in the formulation, interaction between the binding and disintegrating agent and quadratic effect of copovidone. Decreasing the percentage of copovidone and increasing the percentage of crosspovidone decreases the time of disintegration of the tablets (influence of the copovidone/crosspovidone interaction on the disintegration time is shown on Fig. 7).

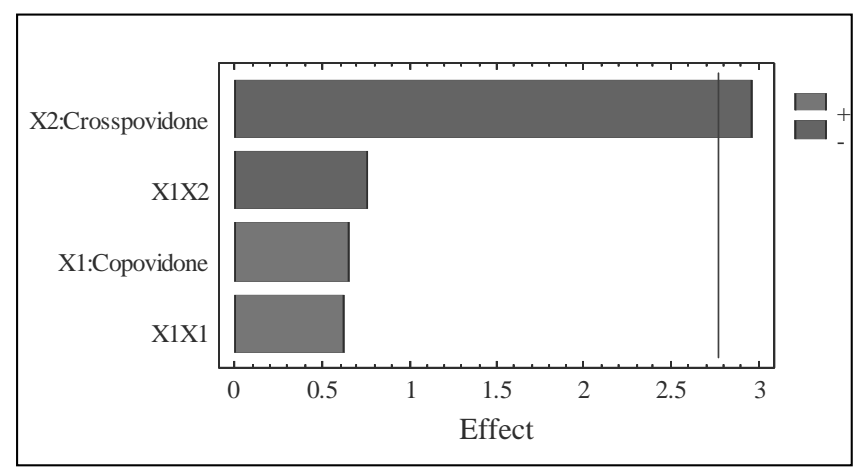

Fig. 9. Standard pareto chart showing the effects of independent variables X1 (copovidone) and X2 (crosspovidone) and their combined effects on the response Y5 (dissolution of diazepam in $0.1 \mathrm{~mol} / 1 \mathrm{HCl}$, for 30 minutes) 


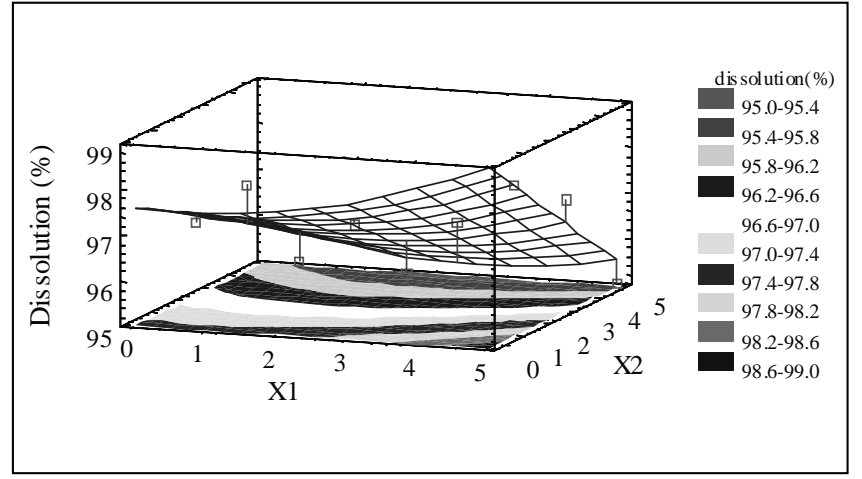

Fig. 10. Response surface plots showing the effect of independent variables, varying ratio of (X1) copovidone and (X2) crosspovidone on response Y5 (dissolution of diazepam in $0.1 \mathrm{~mol} / \mathrm{l} \mathrm{HCl}$ )

Adequately, at level of $1 \%$ of incorporated disintegrating agent, increasing quantity of copovidone will significantly increase the value of the disintegration time for the prepared formulations (Fig. 8 shows response surface plots showing the effect copovidone and crosspovidone on disintegration).

\section{Drug dissolution}

Dissolution of the active ingredient in orally disintegrating tablets starts in the mouth after the fast disintegration where the $\mathrm{pH}$ is approx. 6.8 (6.4-7.2). After the swallowing of the granules or the primary particles the drug dissolution continues at $\mathrm{pH}$ approximately 1.5 and the absorption of the released drug depends on the basic dissolution of the active ingredient and its permeability through the membranes. Diazepam is classified in the second group of biopharmaceutical classification system i.e. is practically insoluble substance at $\mathrm{pH} 6.8$ or at basic $\mathrm{pH}$ and showing good permeability through the biological membranes. Except better patient compliance, fast dispersible/disintegration tablet means avoiding the factors of the disintegration process on the efficacy of the tablet formulation. As diazepam dissolution rate decreases at basic $\mathrm{pH}$, its immediate availability in primary particles for dissolution after reaching the gaster and $\mathrm{pH} 1.5$ might contribute to its better availability for absorption.

The Response Surface design shows that drug release in acidic medium is influenced only by the quantity of disintegrating agent, which is represented in Fig. 9 and Fig. 10 where factor X2 shows the main significant effect.

\section{Conclusion}

Optimization of Diazepam ODT using response surface full factorial design was performed.

The quantity and the ratio of independent variables showed significant effects on the tablet characteristics.

The most significant effect on the hardness of the tablets shows the binding agent copovidone. Increasing the quantity of copovidone increases the hardness of the tablets.

The most significant effect on the friability of the tablets has copovidone, although effect on the friability due to the interaction between copovidone and crosspovidone is also present. With increasing the content of copovidone the percent of friability of the tablets decreases.

The quantity of the copovidone and crosspovidone presents the main effect on the tablet disintegration. Interaction among copovidone and crosspovidone shows significant effect on the disintegration process, also. Increasing the quantity of crosspovidone and decreasing the quantity of copovidone decreases the time of disintegration of the tablets. Faster disintegration of diazepam tablet means that complete drug release will be achieved in medium where the active substance has a good solubility i.e. the influence of the disintegration time of the pharmaceutical dosage form on the dissolution time and of the active component is completely avoided and the dissolution rate and time will depend only on the characteristics of the active ingredient, which if needed might be modified as well. Based on the quantitative effect of the polynomial equations generated by RSM, the optimum formulation from RS design could be formulation with adequate hardness, friability and disintegration time less than 20 sec. Such formulation/s contains copovidone $2.75 \%$ and crosspovidone in a quantity of 3-5 \%. 


\section{References}

1. R. H. Bogner and M. F. Wilkosz, US Pharmacist (2005).

2. G. Mukesh, P. Madhabhai, A. Avani, A. Ruchi, D. Rikita, B. Nehal, AAPS PharmSciTech. 5(3), Art.36 (2004).

3. S. Scheimer, P. C. Schmidt, Eur. J. Pharm. Sci. 15, 295-305 (2002).

4. A. Abu-Izza Khawla, Li H. Vincent, J. L. Look, D. P. Graham, D. Schineller, K. Matthew, US Patent:6 733781 (2004).

5. P. Leesawat, A. Laopongpaisan, J. Sirithunyalug, CMU Journal. 3(2), 97-112 (2004).

6. B. Campisi, D. Chicco, D. Vojnovic, R. Phan-Tan-Luu, J. Pharm. Biomed. Anal. 18, 57-65 (1998).

7. A. Palamakula, M. T. H. Nutan, M. A. Khan, AAPS PharmSciTech. 5(4), Art.66 (2004).

8. B. Singh, S. K. Chakkal, N. Ahuja, AAPS PharmSciTech. 7(1), Art.3 (2006).
9. D. C. Montgomery and R. H. Myers, Response Surface Methodology: Process and Product Optimization Using Designed Experiment, $1^{\text {st }}$ ed., Wiley \& Sohns, New York, 1997.

10. G. E. P. Box, W. G. Hunter and J. S. Hunter, Illustration of Response Surface Methodology; Statistics for Experimentors, Wiley \& Sohns, New York, 1978, pp. 513-526.

11. T. Ozeki, Y. Yasuzawa, H. Katsuyama, T. Takashima, T. Kasai, T. Eguchi, H. Kakiuchi, H. Yuasa, H. Okada, AAPS PharmSciTech. 4(4), Art.70 (2003).

12. K. Rocksloh, F. Rapp, S. Abu-abed, W. Muller, M. Reher, G. Gauglitz, P. C. Schmidt, Drug Dev. Ind. Pharm. 25(9), 1015-25 (1999).

13. R. Huisman, H. V. Van Kamp, J. W. Weyland, D. A. Doornbos, G. K. Bolhuis, C. F. Lerk, Pharm Weekbl Sci. 6(5), 185-94 (1984). 


\title{
Резиме
}

\section{Перорална дисперзибилна таблета: Формулациски дизајн и оптимизација со примена на Response Surface методологија}

\author{
Билјана Несторовска-Ѓошевска*, Марија Главаш-Додов, Катерина Горачинова

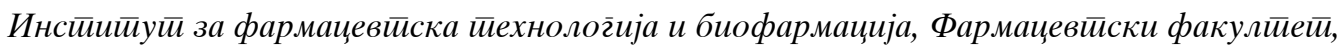 \\ Универзитети „Св. Кирил и Метиояиј“, Воэњанска 17, 1000 Скойје, Макеяонија
}

Клучни зборови: перорална дисперзибилна таблета, експеримантален дизајн, response surface методологија.

Цел на овој труд беше развој на диазепам перорална дисперзибилна таблета и оптимизација на карактеристиките на таблетата со примена на response surface методологијата. Таблетите беа подготвени со директна компресија на мешавина од манитол, коповидон, кросповидон, арома и средство за лубрикација.

Беше применет full factorial дизајн на два фактори на формулацијата, секој поставен на 3 нивоа, со цел да се испита ефектот на двата променливи фактори на формулацијата врз механичката јакост/цврстината, процентот на фријабилност, времето на дезинтеграција на таблетите и дисолуцијата на тешко растворливата активна компонента. Како независни променливи беа земени количините на коповидон и кросповидон. Добиените резултати беа анализирани со примена на соодветна статистичка програма.

Резултатите од мултипната регресија покажаа дека за да се добие дозирана форма со многу брза дезинтеграција, таблетите треба да содржат оптимална концентрација на коповидон и кросповидон.

Ефектот на независните променливи на цврстината на таблетата, времето на дезинтеграција, процентот на фријабилност и дисолуцијата графички е претставен со соодветни контурни нацрти. За да се прикаже валидноста на применетиот математички модел беше подготвена и контролна серија.

Факторијалниот дизајн на 3 нивоа овозможи да се добие перорална дисперзибилна таблета со многу брза дезинтеграција и дисолуција на активната компонента, со задоволителна фријабилност и соодветна механичка јакост (цврстина) на таблетите. 